\title{
Anatomical, physiological and chemical differences between populations of Pseudocyphellaria flavicans (Hook. f. \& Taylor) Vain. from Chile
}

\section{Diferencias anatómicas, fisiológicas y químicas entre poblaciones de Pseudocyphellaria flavicans (Hook. f. \& Taylor) Vain. de Chile}

\author{
Cristian Atala ${ }^{1 *}$, Carlos Schneider², Gabriel Bravo², Manuel Quilodrán² \& Reinaldo Vargas ${ }^{3}$ \\ ${ }^{1}$ Laboratorio de Anatomía y Ecología Funcional de Plantas (AEF), Instituto de Biología, Facultad de Ciencias, \\ Pontificia Universidad Católica de Valparaíso, Campus Curauma. \\ 2Departamento de Ciencias y Tecnología Vegetal, Escuela de Ciencias y Tecnologías, Universidad de Concepción, \\ Campus Los Ángeles. \\ ${ }^{3}$ Herbario Federico Johow, Departamento de Biología, Universidad Metropolitana de Ciencias de la Educación. \\ *cristian.atala@ucv.cl
}

\begin{abstract}
Environmental conditions can affect lichen morphology, physiology and chemistry. Some functional traits; like thickness of thallus layers, photosystems condition, and presence of photoprotective and antioxidant compounds are key to colonizing new sites, and can change depending on light and moisture availability. In the present study, we compared the morphology, physiology and chemistry of the native Chilean lichen Pseudocyphellaria flavicans from two Coastal populations (Nahuelbuta and Contulmo, Araucanía district), and one Andean population (Ralco, Bío-Bío district). Ralco is a more closed secondary forest, and can show dryer periods compared to Nahuelbuta and Contulmo. We found differences in thalli anatomy between populations. Ralco individuals had thinner upper cortex than Nahuelbuta individuals. Contulmo individuals had similar upper cortex thickness compared to the other two populations. We also found differences in the response of the maximal efficiency of the PSII (Fv/Fm) to desiccation and in the in situ values measured. We did not find differences between populations in the chemical traits. The differences between populations could be attributed to differences in local environmental conditions, namely moisture and light.
\end{abstract}

KEYwORDS: Pseudocyphellaria flavicans, lichen ecophysiology, lichen anatomy, lichen chemistry, foliose lichens.

\section{RESUMEN}

Las condiciones ambientales afectan la morfología, fisiología y química de los líquenes. Ciertos rasgos funcionales, como el grosor de las distintas capas del talo, estado de los fotosistemas, y presencia de compuestos fotoprotectores y antioxidantes son claves para colonizar nuevos sitios y pueden variar dependiendo de la disponibilidad de luz y humedad. En este trabajo se comparó la morfología, fisiología y química de individuos del liquen nativo de Chile Pseudocyphellaria flavicans de dos poblaciones de la Cordillera de la Costa (Nahuelbuta y Contulmo, Región de la Araucanía) y una de la Cordillera de los Andes (Ralco, Región del Bío-Bío). Ralco es un bosque más cerrado y presenta periodos más secos, comparado con Nahuelbuta y Contulmo. Se encontraron diferencias significativas en la anatomía del talo entre poblaciones. Los individuos de Ralco presentaron una corteza superior más delgada en relación con los de Nahuelbuta. Los individuos de Contulmo presentaron una corteza similar a las otras dos poblaciones. También se encontraron diferencias en las curvas de respuesta de la eficiencia máxima del PSII (Fv/Fm) a la desecación y los valores medidos in situ. No se encontraron diferencias entre poblaciones en las variables químicas medidas. Las diferencias entre poblaciones podrían atribuirse a diferencias en las condiciones ambientales locales, principalmente humedad y luminosidad.

Palabras clave: Pseudocyphellaria flavicans, ecofisiología de líquenes, anatomía de líquenes, química de líquenes, líquenes foliosos.

\section{INTRODUCTION}

Lichens result from the symbiotic association of at least one algal species (the photobiont) and one fungal species (the mycobiont). The stable association of both partners (holobiont) allows lichens to grow in different habitats and conditions, tolerating extremely stressful environments such as deserts and Polar Regions (Kappen \& Breuer 1991, Kappen
2000, Kappen \& Valladares 2007, Wirth et al. 2007). Foliose lichens (lichens with leaf-like habit) normally have clearly distinct layers: an upper cortex formed by glutinized hyphae where derivates from the secondary metabolism precipitate; an algal layer where the photobiontal cells are distributed; a medullae formed by loosely attached hyphae that allows the exchange of gases necessary for photosynthesis; and a lower cortex with different structures for attachment (i.e. rhizines, 
rhizinose strands, hapteria, etc., Büdel \& Scheidegger 2008). Many anatomical, ecophysiological and chemical traits in foliose lichens depend on environmental conditions (Snelgar \& Green 1981, Green \& Langue 1991, Gauslaa et al. 2006). This is also true for photobiont availability, which may determine the presence of a given species in a particular environment (Beck et al. 2002, Yahr et al. 2006, Fernández-Mendoza et al. 2011, Vargas \& Beck 2012, Nyati et al. 2013, 2014). Total thallus, upper cortex, algal layer and medulla thickness, for example, are increased in lichens highly exposed to sunlight, and even an epinecral layer is formed as protection to high sun exposition in some cases (Büdel 1990, Gaya 2009). Also, an increase in the amount of lichen metabolites that precipitate in the upper cortex have been observed, probably as an anti-UV screening system (Beckett et al. 2008, Green \& Lange 1991). It has also been stated that high intensity light might induce the synthesis of melanic compounds and other colored metabolites with antioxidative properties, suggesting a functional response to high light (Solhaug et al. 2003). On the other hand, structural differences can have functional consequences, for example, in water storage capacity (Sancho \& Kappen 1989, Valladares et al. 1993). Environmental conditions can also impact the reproductive output of the lichen, altering the formation of sexual structures (Ramstad \& Hestmark 2001, Mikhailova 2007), and the vegetative reproduction of the whole lichen, altering the number of isidia and soredia per area (Mikhailova \& Vorobeichik 1999, Mikhailova 2002, Sojo et al. 2008).

Lichens also alter their physiology in response to changes in abiotic conditions. Gas exchange, normally small in lichens, is highly dependent on water availability, as high amounts of water reduces the net carbon gain of the holobiont (Leisner et al. 1997, Beckett et al. 2008). The response of carbon gain to thallus water content, however, is not always simple. Most species reduce their photosynthesis at low water potentials, but some species also show a reduction at high water content (Green \& Lange 1991), possibly due to increased diffusion resistance to $\mathrm{CO}_{2}$ (Nash 2008). Small reductions in water potential can negatively impact photosynthesis and drop the maximal efficiency of PSII (Fv/Fm) below optimal values (Beckett et al. 2005, Kappen \& Valladares 2007).

Members of the genus Pseudocyphellaria are very conspicuous, with some species among the largest known foliose lichens, often reaching up to $50 \mathrm{~cm}$ in diameter (Galloway 1992). They have heteromerous thalli with cyanobacterial or algal photobionts (Galloway 1992). The genus is characterized by the presence of scattered (sometimes very sparse) pseudocyphellae on the lower surface, and sometimes also in the upper surface. Pseudocyphellaria flavicans (Hook. f. \& Taylor) Vain. is a corticolous lichen that can be found in Chile and Argentina, the Juan Fernandez Archipelago and from $37^{\circ} 50^{\prime} \mathrm{S}$ southwards to Tierra del Fuego and Staten Island in Argentina (Galloway 1992). The species can be found in a variety of habitats and it is an epiphyte of shrubs and trees in areas with high humidity, in moderate to high light intensity areas, usually inside undisturbed temperate forests, from sea level up to $1500 \mathrm{~m}$ (Vainio 1913, Galloway 1992).

The present study addresses if three populations of P. flavicans from Southern Central-Chile differ in their anatomical, physiological and chemical traits, in relation to local environmental conditions; namely light and water availability. We selected thalli from one Andean population and from two populations from Nahuelbuta Mountain Range, close to the coast. The Andean population is located in a closed secondary forest, close to the town of Ralco, inside a protected area. Both Costal populations are located also in secondary forests inside protected natural areas but receive higher precipitation throughout the year compared to the Andean population (Di Castri \& Hajek 1976), mainly due to the oceanic influence.

\section{MATERIALS AND METHODS}

\section{SAMPLES}

Thalli of Pseudocyphellaria flavicans were collected from the field and stored in the laboratory. Samples were obtained from three populations: Nahuelbuta National Park (Malleco, Nahuelbuta Mountain Range, 3747' S - 7259' W, $\sim 800$-1000 masl), Contulmo Natural Monument (Malleco, Nahuelbuta Mountain Range, $38^{\circ} 01^{\prime}$ S - 7310' W, 300-400 masl), and Ralco National Reserve (Bío-Bío, Andes, 3751' $\left.\mathrm{S}-71^{\circ} 19^{\prime} \mathrm{W}, \sim 1200 \mathrm{masl}\right)$. The first two sites correspond to protected natural areas close to the coast. Ralco correspond to a protected area in the Andes, with almost undisturbed, natural vegetation. Thalli were collected from September 2012 (Austral spring) to January 2013 (Austral summer). We took 10 hemispherical photos per site in the exact locations of the studied thalli. These photos were then analyzed with GLA software (Frazer et al. 1999) to calculate canopy openness, a measure of the light environment of the lichens.

\section{ANATOMICAL TRAITS}

We compared the number of isidia and apothecia per area in 5 randomly selected thalli per site. The reproductive structures were counted in $1 \mathrm{~cm}^{2}$ area, under an optical magnifier. Measures were made at $3 \mathrm{~cm}$ from the thallus margin.

On the same thalli we performed transversal section at 3 $\mathrm{cm}$ from the edge. We took digital photographs using an optical microscope (Primo Star, Carl Zeiss, Germany) with an attached digital camera (Canon EOS Rebel XS). We then measured the thickness of the upper cortex, algal layer, medullae, and lower cortex using image software (Axiovision Rel. 4.8).

ECOPHYSIOLOGICAL TRAITS

Sections of thalli from the field were put in hermetic plastic bags and transported to the laboratory where they were 
kept for 1 week at room temperature in the dark. At the beginning of the desiccation experiment, 30 thalli segment per population were weighted with a digital scale (Baxtran PS1000). Fragments were then fully hydrated with tap water until constant weight was reached. Lastly, thalli were dried for $630 \mathrm{~min}$ at room temperature and weight was measured periodically every $35 \mathrm{~min}$ (see below). Relative water content was calculated as:

$\mathrm{RWC}=\frac{\text { (fresh weight-dry weight) }}{\text { (fully hydrated weight-dry weight) }}$

RWC was used instead of water content (WC) because is commonly used in ecophysiological studies of desiccationtolerant organisms and allows inter-species comparisons (see Atala et al. 2014). Maximal WC (fully hydrated weight) is difficult, but not impossible, to obtain in lichens, usually taking many hours to reach constant weight.

To determine the maximum efficiency of the PSII (Fv/Fm) we used a portable fluorimeter (Pocket PEA, Hansatech Ltd, King's Lynn, UK). Samples were collected and transported to the laboratory as described above. Following the same procedure described for the RWC, we measured Fv/Fm every $35 \mathrm{~min}$ up to $630 \mathrm{~min}$. This experiment was conducted in the dark and samples were dark-adapted for $45 \mathrm{~min}$ previous to the first measurement of $\mathrm{Fv} / \mathrm{Fm}$. Temperature and relative humidity $(\mathrm{RH})$ were constant at the time measurements were conducted. All populations were measured simultaneously, separating individual measurements by 2-5 min intervals. Fv/Fm was not expressed on an area basis because the used instrument determinate fluorescence parameters on a fixed leaf area.

Chemical ANALYsis

For the antioxidant analysis, the material was dried at room temperature under shade after washing with distilled water. After drying, the material was cleaned under a magnifying glass and impurities were removed. A methanol extract was prepared by soaking $0,770 \mathrm{~g}$ of thalli each populations from in $210 \mathrm{~mL}$ of solvent. The maceration process of the extracts was performed during one hour at room temperature. The extracts were filtered and solvent was evaporated using a rotatory evaporator (IKA, RV10 digital) at $50{ }^{\circ} \mathrm{C}$. Extracts were then filtered and concentrated. The crude extract was kept at $4{ }^{\circ} \mathrm{C}$. The free radical scavenging activity of Pseudocyphellaria flavicans extract was measured by 1,1-diphenyl-2-picrylhidrazyl (DPPH) (SIGMA). The ability of lichen extract to scavenge DPPH free radicals (\%) was calculated according to the method described by Takao et al. (1994) with some modifications.

An aliquot of $2 \mathrm{ml}$ of the extracted fraction (5, 40, 200, 400, 500, 1000 and $2000 \mu \mathrm{g} / \mathrm{ml}$ ) was mixed with 2 $\mathrm{ml}$ (freshly) prepared DPPH solution in a concentration of $80 \mu \mathrm{g} / \mathrm{ml}$. After $30 \mathrm{~min}$ incubation in dark at ambient temperature, the resultant absorbance was measured at 517 $\mathrm{nm}$ against a blank on a spectrophotometer (Genesys 10 UV, Thermoscientific). The IC50 values (concentration of extract in the reaction mixture needed to decrease by $50 \%$ the initial DPPH concentration) were determined by polynomial regression analysis of the obtained DPPH radical scavenging (\% inhibition). The inhibition concentration (IC50) was the parameter used to compare the radical scavenging activity between the three Pseudocyphellaria flavicans populations. Analyses were done in triplicate (3 per population). All measurements were done within a month.

\section{Statistical anAlyses}

To analyze differences in traits between populations we conducted a one-way ANOVA and used the Tukey test as an $a$ posteriori test. Fv/Fm curves were compare using a repeatedmeasures ANOVA. Standard errors were not included in Figure 1 to avoid confusion and crowding in the figure. Additionally, errors were small and usually fell within the dot in the graph $(2-3 \%)$.

TABLE I. Ecological, anatomical and chemical traits of P. flavicans individuals from three populations. Contulmo and Nahuelbuta are Coastal populations and Ralco is an Andean population. Different letters show statistical differences (Tukey test, $\mathrm{p}<0.05$ ).

TABla I. Rasgos ecológicos, anatómicos y químicos en individuos de P. flavicans de tres poblaciones. Contulmo y Nahuelbuta son poblaciones costeras y Ralco es una población de Los Andes. Letras diferentes indican diferencias estadísticas (test de Tukey, p<0.05).

\begin{tabular}{|c|c|c|c|c|}
\hline Population & GAP OPENNESS (\%) & UPPER CORTEX THICKNESS $(\mu \mathrm{m})$ & ISIDIA $/ \mathrm{cm}^{2}$ & ANTIOXIDANT ACTIVITY (IC50, $\mu \mathrm{g} / \mathrm{mL})$ \\
\hline Contulmo & $27.5 \pm 8.0^{\mathrm{a}}$ & $35.8 \pm 3.9^{\mathrm{ab}}$ & $34.4 \pm 5.8^{\mathrm{a}}$ & $474.1 \pm 94.7^{\mathrm{a}}$ \\
\hline Nahuelbuta & $31.8 \pm 5.5^{\mathrm{a}}$ & $57.0 \pm 5.4^{\mathrm{a}}$ & $72.6 \pm 3.1^{b}$ & $520.1 \pm 106.5^{\mathrm{a}}$ \\
\hline Ralco & $19.1 \pm 5.8^{b}$ & $27.6 \pm 3.1^{\mathrm{b}}$ & $77.2 \pm 6.9^{b}$ & $432.1 \pm 59.4^{\mathrm{a}}$ \\
\hline
\end{tabular}




\section{RESULTS}

We found differences in the light environment experienced by the thalli of the three populations (Table I, ANOVA $\mathrm{p}<0.001)$. Ralco thalli were exposed to a more closed canopy compared to both Coastal populations (Table I, Tukey test $\mathrm{p}<0.05)$. There were no differences in canopy openness between Nahuelbuta and Contulmo thalli (Table I, Tukey test $\mathrm{p}>0.05$ ).

ANATOMICAL TRAITS

The three populations of Pseudocyphellaria flavicans differed in their anatomy. Individuals from the Andean population (Ralco) had thinner upper cortex compared to Nahuelbuta (Table I, Tukey test $\mathrm{p}<0.05$ ). There were no differences in upper cortex thickness between both coastal populations and between Ralco and Contulmo (Table I, Tukey test $\mathrm{p}>0.05$ ). All three populations did not show statistical difference in algal layer, medullae, or lower cortex thickness (ANOVA $p>0.05$, data not shown). Total thalli thickness followed the same pattern as upper cortex thickness (Tukey test $\mathrm{p}<0.05$, data not shown).

We found differences in the number of isidia $/ \mathrm{cm}^{2}$ between populations (Table I, ANOVA $\mathrm{p}<0.05$ ). Contulmo individuals had lower isidia density compared to Nahuelbuta and Ralco (Table I, Tukey test, $\mathrm{p}<0.05$ ). There were no differences in isidia/ $\mathrm{cm}^{2}$ between Nahuelbuta and Ralco (Table I, Tukey test, $\mathrm{p}<0.05$ ). Apothecia were scarce in all populations. We only found three individuals with few evident apothecia in the Contulmo population and two in the Nahuelbuta population. They averaged 1-2 apothecia/cm2 (data not shown).

\section{Physiological AND CHEMICAL TRAITS}

Thalli from all populations loosed water similarly when desiccated (Fig. 1). However, the Fv/Fm changed differently when desiccating in the three populations (Fig. 1, Repeated Measures ANOVA, $\mathrm{p}<0.001)$. All populations maintained a relatively constant $\mathrm{Fv} / \mathrm{Fm}$ up to $50-60 \%$ RWC. After that, the Fv/Fm dropped. Ralco and Nahuelbuta individuals had a similar Fv/Fm kinetic when desiccating, but they had different initial values (at $100 \%$ RWC, data not shown). Contulmo thalli dropped their Fv/Fm more rapidly compared to Ralco and Nahuelbuta populations (Fig. 1). After $250 \mathrm{~min}$ of desiccation for Contulmo and $400 \mathrm{~min}$ for Nahuelbuta and Ralco, corresponding to almost $0 \% \mathrm{RWC}, \mathrm{Fv} / \mathrm{Fm}$ dropped to $20-30 \%$ of the initial values, and stabilized up to the end of the experiment (Fig. 1).

The extracts from the different populations showed free radical scavenging activity, but there were no statistically significant differences in the IC50 values between the studied Pseudocyphellaria flavicans populations (Table I, ANOVA, $\mathrm{p}>0.05)$.
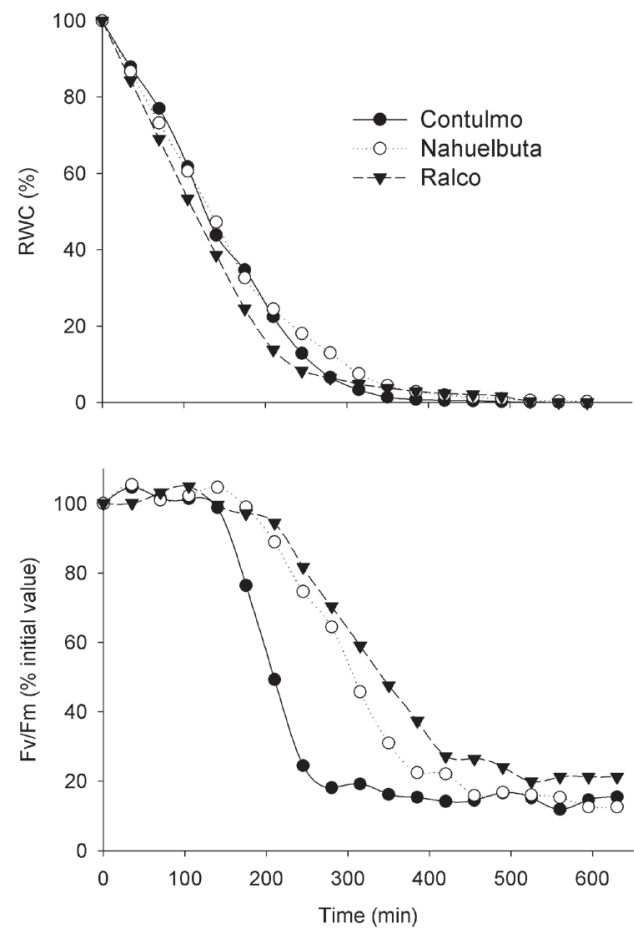

Figure 1. Response of the Fv/Fm (maximal efficiency of the PSII) and relative water content (RWC) to desiccation in P. flavicans thalli from three populations. Contulmo and Nahuelbuta are Coastal populations and Ralco is an Andean population. $n=30$ per population. Populations statistically differed in their Fv/Fm (Repeated Measures ANOVA, $\mathrm{p}<0.001)$. Fv/Fm values are expressed as $\%$ of initial measurement.

Figura 1. Respuesta del Fv/Fm (eficiencia máxima del fotosistema II) y contenido relativo de agua (RWC) a la desecación en talos de $P$. Alavicans de tres poblaciones. Contulmo y Nahuelbuta son poblaciones costeras y Ralco corresponde a una población Andina. $n$ $=30$ por población. Se encontraron diferencias estadísticas en el Fv/ Fm entre las poblaciones (ANDEVA de medidas repetidas, $\mathrm{p}<0.001$ ). Los valores de $\mathrm{Fv} / \mathrm{Fm}$ corresponden al \% del valor inicial medido.

\section{DISCUSSION}

The studied populations differed in anatomical and physiological traits. However, there were no differences between populations in the chemical traits included in our study. Both coastal populations tended to be similar in several traits, possibly reflecting the similar climatic conditions of both sites (Di Castri \& Hajek 1976, Luebert \& Pliscoff 2006). On the other hand, Nahuelbuta and Ralco populations were physiologically similar, possibly reflecting their similar altitudes and the resulting climatic convergences (Di Castri \& Hajek 1976, Luebert \& Pliscoff 2006). The 
Andean population was located in a more closed (older) forest compared to coastal populations. Additionally, costal populations receive higher precipitation compared to the Andean population, particularly the Contulmo population (Di Castri \& Hajek 1976, Luebert \& Pliscoff 2006).

The different light environments resulted in differences in anatomical traits such as upper cortex thickness. Both coastal populations were located in more open sites and Nahuelbuta individuals had thalli with thicker upper cortex compared to the other two populations. This higher upper cortex thickness might reflect part of the incident radiation (Büdel 1990) and usually contains antioxidants and anti-UV compound (Solhaug et al. 2003, Manojlovic et al. 2012). A thicker upper cortex has also been found in other light-exposed lichens, and it has been related to a direct result from direct sunlight exposition (Beckett et al. 2008, Green \& Lange 1991), protecting algae from excess light, heat and photoinhibition. Other strategies to cope with high light intensity have been discussed for other groups of lichens. For example, stacking of the algae and fungal mycelia allow lichens to disperse the light and to lower the effect of direct sunlight (Vondrák \& Kubásek 2013). Antioxidant capacity, however, was not statistically different in the three populations. This could be due to the low sample size or maybe the structural differences between populations were sufficient to cope with the differences in light and moisture between sites. Snelgar \& Green (1981) considered the length of the rhizines as a functional trait related to water retention capability in more exposed sites. Their study was based on Pseudocyphellaria dissimilis, a species with a constant tomentum in the lower surface. This is in strong opposition with P. flavicans that has an unevenly distributed tomentum in the lower surface that is almost absent in the margins. Thus measurements of the rhizines would not have been functionally equivalent to the mentioned study on $P$. dissimilis.

Environmental conditions also seemed to affect the reproductive output of the lichens. Individuals from Contulmo had lower vegetative reproductive output compared to the other two populations. In Contulmo, there seems to be a higher lichen density per tree, resulting in higher competition (Atala \& Vargas, unpublished data). In such conditions, it has been suggested that sexual reproduction is favored over asexual reproduction (Lücking 1999). Nevertheless, few apothecia were found in Contulmo thalli. Ralco individuals showed no apothecia at all, location where competition seemed limited due to the reduced lichen diversity and abundance (Atala et al., unpublished data).

All populations reduced their RWC similarly when left to dehydrate. Individuals from Contulmo (moister site), however, reduced their $\mathrm{Fv} / \mathrm{Fm}$ faster than the other two populations. When the RWC dropped to 50-40\%, all thalli dropped their FV/ $\mathrm{Fm}$, reaching values close to 0.1 (absolute value) in less than an hour. Individuals from Nahuelbuta had a lower initial Fv/ Fm compared to the other two populations ( 0.4 vs. 0.6 , data not shown), but the relative Fv/Fm curve behaved similarly to
Ralco in terms of slope. These differences in the Fv/Fm when dehydrating could be due to ecotypic differentiation between populations, although plasticity cannot be ruled out. After 400 min lichen from all populations dropped their Fv/Fm to values close to 0.1 ( $\sim 20 \%$ of initial $\mathrm{Fv} / \mathrm{Fm})$ and remained constant until the end of the experiment (630 $\mathrm{min})$.

Lichens, in general, are understudied organism, especially in Chile (but see Quilhot et al. 2012, Rubio et al. 2013, Vargas et al. 2013). This study is one of the first ecophysiological studies on Chilean Pseudocyphellaria. We found differences in functional traits between populations of $P$. flavicans but we currently do not know the underlying mechanisms explaining such differences. Future studies should address is $P$. flavicans populations can show plasticity in functional traits and/or local adaptation to light and water availability.

\section{ACKNOWLEDGEMENTS}

We would like to thank CONAF Araucanía staff for field support and logistic help. We also thank two anonymous reviewers whose comments greatly improved this paper.

\section{REFERENCES}

Armstrong, R.A. 1991. Experimental studies of lobe growth in the lichen Parmelia conspersa (Ehrh. ex Ach.) Ach. New Phytologist 119: 315-319.

Armstrong, R.A. \& T. Bradwell. 2011. Growth of foliose lichens: a review. Symbiosis 53: 1-16.

Atala, C., J.P. Alfaro, M.J. Parra \& A. Saldaña. 2014. Desiccation tolerance in Dendroligotrichum dendroides (Brid. ex Hedw.) Broth. from two Chilean populations with contrasting precipitation. Gayana Botánica 71(1): 10-16.

Beck, A., T. Kasalicky \& G. Rambold. 2002. Myco-photobiontal selection in a Mediterranean cryptogam community with Fulgensia fulgida. New Phytologist 153: 317-326.

Beckett, R.P., I. Kranner \& F.V. Minibayeva. 2008. Stress physiology and the symbiosis. In: T.H. Nash III (ed.): Lichen Biology, Second Edition, pp. 134-151. Cambridge University Press, Cambridge, UK.

Beckett, R.P., N. Mayaba, F.V. Minibayeva \& A. Alyabyev. 2005. Hardening by partial dehydration and ABA increase desiccation tolerance in the cyanobacterial lichen Peltigera polydactylon. Annals of Botany 96(1): 109-115.

Büdel, B. \& C. SCHEIDEGGer. 2008. Thallus morphology and anatomy. In: T.H. Nash III (ed.): Lichen Biology, Second Edition, pp. 40-68. Cambridge University Press, Cambridge, UK.

BüDEL, B. 1990. Anatomical adaptations to the semiarid/arid environment in the lichen genus Peltula. Bibliotheca Lichenologica 38: 47-61.

Dere, S., T. Gunes \& R. Sivaci. 1998. Spectrophotometric determination of chlorophyll a, b and total carotenoid contents of some algal species using different solvents. Trends Journal of Botany 22: 13.

Di CAStRi, F. \& E.R. HajeK. 1976. Bioclimatología de Chile. Editorial de la Universidad Católica de Chile, Santiago, Chile. 129 pp. 
Fernández-Mendoza, F., S. Domaschke, M.A. García, P. Jordan, M.P. Martín \& C. Printzen. 2011. Population structure of mycobionts and photobionts of the widespread lichen Cetraria aculeata. Molecular Ecology 20(6): 1208-1232.

Frazer, G.W., C.D. Canham \& K.P. Lertzman. 1999. Gap Light Analyzer (GLA), Version 2.0: Imaging software to extract canopy structure and gap light transmission indices from true-colour fisheye photographs, user's manual and program documentation. $40 \mathrm{pp}$.

Galloway, D.J. 1992. Studies in Pseudocyphellaria (lichens) III. The South American species. Bibliotheca Lichenologica 46: 1-275.

Gauslaa, Y., M. Lie, K.A. Solhaug \& M. Ohlson. 2006. Growth and ecophysiological acclimation of the foliose lichen Lobaria pulmonaria in forests with contrasting light climates. Oecologia 147: 406-416.

GAYA, E. 2009. Taxonomical Revision of the Caloplaca saxicola Group (Teloschistaceae, Lichen-forming Ascomycota). Bibliotheca Lichenologica 101: 1-191.

GreEn, T.G.A. \& O.L. LANGe. 1991. Ecophysiological adaptations of the lichen genera Pseudocyphellaria and Sticta to south temperate rainforests. Lichenologist 23(3): 267-282.

Kappen, L. 2000. Some aspects of the great success of lichens in Antarctica. Antarctic Science 12(3): 314-324.

Kappen, L. \& M. Breuer. 1991. Ecological and physiological investigations in continental Antarctic cryptogams. II. Moisture relations and photosynthesis of lichens near Casey Station, Wilkes Land. Antarctic Science 3(3): 273-278.

Kappen, L. \& F. Valladares. 2007. Opportunistic Growth and Desiccation Tolerance: The Ecological Success of Poikilohydrous Autotrophs. In: F. Pugnaire \& F. Valladares (eds.), Functional plant ecology, pp. 7-65. Taylor and Francis, New York.

Leisner, J.M.R., T.G.A. Green \& O.L. Lange. 1997. Photobiont activity of a temperate crustose lichen: long-term chlorophyll fluorescence and $\mathrm{CO}_{2}$ exchange measurements in the field. Symbiosis 23: 165-182.

LÜCKING, R. 1999. Ecology of foliicolous lichens at the 'Botarrama' trail (Costa Rica), a neotropical rainforest. IV. Species associations, their salient features and their dependence on environmental variables. Lichenologist 31: 269-289.

Luebert, F. \& P. Pliscoff. 2006. Sinopsis bioclimática y vegetacional de Chile. Editorial Universitaria. 313 pp.

Manojlovic, N.T., P.T. Vasiljevic \& P.Z. Maskovic. 2012. Chemical composition and antioxidant activity of lichen Toninia candida. Revista Brasileira de Farmacognosia 22(2): 291-298.

Mikhailova, I.N. \& E.L. VorobeichiK. 1999. Dimensional and age structure of populations of epiphytic lichen Hypogymnia physodes (L.) Nyl. under conditions of atmospheric pollution. Russian Journal of Ecology 30: 111-118.

Mikhailova, I.N. 2002. Vegetative reproduction of Hypogymnia physodes (L.) Nyl. under conditions of air pollution. Bibliotheca Lichenologica 82: 243-249.

Mirhailova, I.N. 2007. Populations of epiphytic lichens under stress conditions: survival strategies. Lichenologist 39(1): 83-89.

Nyati, S., S. Werth \& R. Honegger. 2013. Genetic diversity of sterile cultured Trebouxia photobionts associated with the lichenforming fungus Xanthoria parietina visualized with RAPDPCR fingerprinting techniques. Lichenologist 45: 825-840.
Nyati, S., S. Scherrer, S. Werth \& R. Honegger. 2014. Green-algal photobiont diversity (Trebouxia spp.) in representatives of Teloschistaceae (Lecanoromycetes, lichen-forming ascomycetes). The Lichenologist 46(2): 189-212.

Pfeifhofer, H.W., R. Willfurth, M. Zorn \& I. Kranner. 2002. Analysis of chlorophylls, carotenoids, and tocopherols in lichens. In: I. Kranner, R.P. Beckett \& A.K. Varma (eds.), Protocols in Lichenology. Culturing, Biochemistry, Ecophysiology and Use in Biomonitoring, pp. 363-378. Springer-Verlag, Berlin, Heidelberg, Germany.

Quilhot, W., M. Cuellar, R. Díaz, F. Riquelme \& C. Rubio. 2012. Lichens of Aysen, Southern Chile. Gayana Botánica 69(1): 57-87.

Ramstad, S. \& G. Hestmark. 2001. Population structure and sizedependent reproductive effort in Umbilicaria spodochroa. Mycologia 93(3): 453-458.

Rubio, C, M. SaAvedra, M. Cuéllar, R. Díaz \& W. Quilhot. 2013. Epiphytic lichens of Conguillío National Park, Southern Chile. Gayana Botánica 70(1): 66-81.

SANCHO, L.G. \& L. KAPPEN. 1989. Photosynthesis and water relations and the role of anatomy in Umbilicariaceae (Lichens) from central Spain. Oecologia 81: 473-480.

SNelgar, W.P. \& T.D.A. GreEN. 1981. Ecologically-linked variation in morphology, actyelene reduction, and water relations in Pseudocyphellaria dissimilis. New Phytologist 87: 403-411.

Sojo, F., F. VAlladares \& L.G. SAnCH. 2008. Structural and physiological plasticity of the lichen Catillaria corymbosa in different microhabitats of the maritime Antarctica. The Bryologist 100 (2): 171-179.

Solhaug, K.A., Y. Gauslaa, L. Nybakken \& W. Bilger. 2003. UV-induction of sun-screening pigments in lichens. New Phytologist 158(1): 91-100.

Takao, T., F. Kitatani, N. Watanabe, A. Yagi \& K. Sakata. 1994. A simple screening method for antioxidants and isolation of several antioxidants produced by marine bacteria from fish and shellfish, Bioscience. Biotechnology and Biochemistry 58(10): 1780-1783.

VAINIO, E.A. 1913. Lichenes Insularum Philippinarum II. Philippine Journal of Science, C. Botany 8(2): 99-137.

Valladares, F., J. Wierzcho \& S.C. Ascas. 1993. Porosimetric study of the lichen family Umbilicariaceae: anatomical interpretation and implications for water storage capacity of the thallus. American Journal of Botany 80: 263-272.

VARGas, R. \& A. Beck. 2012. Photobiont selectivity and specificity in Caloplaca species in a fog-induced community in the Atacama Desert, northern Chile. Fungal Biology 116: 665-676.

Vargas, R., A. Ibaceta \& E. Vergara. 2013. Rinodina pyrina (Physciaceae, Ascomycota), nueva especie para Chile. Gayana Botánica 70(2): 366-368.

VondRÁK, J. \& J. KuBÁSEK. 2013. Algal stacks and fungal stacks as adaptations to high light in lichens. The Lichenologist 45(1): 115-124.

Wirth, V., K. Loris \& J. Müller. 2007. Lichens in the fog zone of the Central Namib and their distribution along an oceaninland transect. Bibliotheca Lichenologica 95: 555-582.

YAhr, R., R. Vilgalys \& P.T. Depriest. 2006. Geographic variation in algal partners of Cladonia subtenuis (Cladoniaceae) highlights the dynamic nature of a lichen symbiosis. New Phytologist 171: 847-860.

Recibido: 31.03 .14

Aceptado: 19.08 .14 